\title{
FORMULASI SEDIAAN GEL EKSTRAK ETANOL BUNGA KUBIS MERAH (Brassica oleracea L.) SEBAGAI ANTIOKSIDAN DENGAN METODE DPPH
}

\author{
Ferry Effendi ${ }^{1 *}$., M Ikhwan Setiawan ${ }^{2}$, Ayu Lestari ${ }^{3}$ \\ 1. Program Studi Farmasi Sekolah Tinggi Teknologi Industri dan Farmasi Bogor \\ 2. Program Studi Farmasi Sekolah Tinggi Teknologi Industri dan Farmasi Bogor \\ 3. Mahasiswa Program Studi S1 Farmasi Sekolah Tinggi Teknologi Industri dan Farmasi Bogor \\ *Korespondensi: f312ye@gmail.com
}

\begin{abstract}
ABSTRAK
Bunga kubis merah (Brassica oleracea L.) mengandung senyawa antioksidan dengan potensi aktivitas yang kuat. Penelitian ini bertujuan untuk membuat sediaan gel antioksidan dengan menggunakan HPMC sebagai basis gel yang mengandung ekstrak etanol bunga kubis merah dengan konsentrasi ( $\%$ b/b) untuk F1, F2 dan F3 adalah 5\%, 7,5\% dan 10\%, yang kemudian dievaluasi dan diuji aktivitas antioksidannya. Pengujian aktivitas antioksidan dilakukan dengan metode penentuan $\mathrm{IC}_{50}$ menggunakan pereaksi DPPH (Difenil-2-pikrilhidrazil). Dari penelitian diperoleh nilai $\mathrm{IC}_{50}$ untuk ekstrak etanol bunga kubis merah dan Vitamin $\mathrm{C}$ sebagai senyawa pembanding adalah 47,10 ppm dan $6,30 \mathrm{ppm}$. Aktivitas antioksidan ekstrak etanol bunga kubis merah dalam sediaan gel pada masing-masing formulasi memiliki nilai $\mathrm{IC}_{50}$ sebesar $80,15 \mathrm{ppm}$ (F1),59,71 ppm (F2), dan 57,48 ppm (F3). Evaluasi sediaan gel meliputi pengamatan homogenitas, organoleptik, viskositas dan $\mathrm{pH}$. Hasil uji sifat fisik sediaan gel menunjukkan bahwa semua sediaan gel homogen, memiliki $\mathrm{pH}$ antara 5,30-5,70 yang sesuai dengan $\mathrm{pH}$ kulit, dengan nilai viskositas 3000-3700 cps, dan memiliki daya sebar $\leq 7 \mathrm{~cm}$. Berdasarkan hasil penelitian ini, disimpulkan bahwa ekstrak etanol bunga kubis merah dapat diformulasikan dalam sediaan gel antioksidan dengan konsentrasi terbaik adalah $10 \%$.
\end{abstract}

\section{Kata Kunci: Antioksidan, DPPH, Bunga kubis merah, Gel}

\begin{abstract}
Red cabbage flower (Brassica oleracea L.) contains antioxidant compounds with strong activity potential. This research aims to make antioxidant gel preparations using HPMC as a base gel containing red cabbage flower extract with concentrations (\% b/b) for F1, F2 and F3 are 5\%, 7,5\% and $10 \%$, which are then evaluated and tested its antioxidant activities. Testing antioxidant activity is carried out by the determination method of $\mathrm{IC}_{50}$ using the reagent DPPH (Difenil-2Pikrilhidrazil). From research acquired the value of $\mathrm{IC}_{50}$ for ethanol extract red cabbage flower and vitamin $\mathrm{c}$ as comparative compounds is $47,10 \mathrm{ppm}$ and $6,30 \mathrm{ppm}$. Antioxidant activity of red cabbage flower ethanol extract in gel preparations in each formulation has a $\mathrm{IC}_{50}$ value of 80,15 $\mathrm{ppm}(\mathrm{F} 1), 59,71 \mathrm{ppm}(\mathrm{F} 2)$, and 57,48 ppm (F3). Evaluation ofgel preparation includes homogenity, organoleptic, viscosity and $\mathrm{pH}$. The physical properties test results of gel dosage showed that all the preparations of the homogeneous gel, have a $\mathrm{pH}$ between the 5,30-5,70 corresponding to the skin $\mathrm{pH}$, with a viscosity value of $3000-3700 \mathrm{cps}$, and have a coverage of $\leq 7 \mathrm{~cm}$. Based on the results of this study, it was concluded that red cabbage flower ethanol extract can be formulated in an antioxidant gel with the best concentration is $10 \%$.
\end{abstract}

Keywords: Antioxidant, DPPH, Red Cabbage Flower, Gel 


\section{PENDAHULUAN}

Indonesia mempunyai keanekaragaman tanaman terbesar kedua di dunia setelah Brazil. Keanekaragaman tanaman di Indonesia, mempunyai potensi sebagai sumber obat baru. Salah satu tanaman tersebut adalah kubis merah. Kubis merah (Brassica oleracea L.) atau dikenal juga sebagai kubis ungu merupakan salah satu hasil pertanian yang keberadaannya kini cukup dikenal oleh masyarakat.

Tumbuhan kubis (Brassica oleracea L.) termasuk dalam famili Brassicaceae, merupakan sayuran yang banyak dibudidayakan para petani di pedesaan Indonesia, karena banyak mengandung vitamin $\mathrm{A}, \mathrm{B}$ dan $\mathrm{C}$ [1]. Berdasarkan penelitian Rokayya, et al., (2013) dalam mengetahui potensi antioksidan pada varietas kubis, diperoleh antioksidan tertinggi terdapat pada kubis ungu (Brassica oleracea L.) [2] dan menurut penelitian Wahyuni, (2017) ekstrak etanol kubis ungu memiliki aktivitas antioksidan yang sangat kuat dengan nilai IC50 44,64 ppm [3]. Untuk memanfaatkannya, selain dikonsumsi sebagai olahan makanan dan minuman atau digunakan dalam sediaan oral, ekstrak kubis merah juga dapat diformulasikan sebagai zat aktif dalam sediaan semipadat yang tujuannya digunakan pada kulit.

Gel merupakan sediaan semi padat atau kental, yang dibuat dengan mencampur ekstrak (zat aktif) dengan basis yang sesuai [4] (Agoes, 2009). Basis air dalam membentuk gel memiliki kemampuan melembabkan dengan bahan yang mengandung banyak air, memiliki efek sejuk yang baik digunakan pada cuaca panas dan sesuai untuk kulit berminyak [5]. Kemampuan melembabkan suatu sediaan seperti pada gel juga memberikan efek melembutkan, menghilangkan garis dan kerutan serta mencegah iritasi pada kulit [6].

Sediaan bentuk gel jarang dijumpai di pasaran dibandingkan bentuk krim atau lotion. Pengaruh lingkungan seperti sinar ultraviolet, asap rokok dan polutan dapat mempercepat terjadinya penuaan dini. Untuk mengetahui sejauh mana potensi sediaan topikal berupa gel dari ekstrak etanol bunga kubis merah (Brassica oleracea L.) dengan konsentrasi 5\%, $7.5 \%$ dan $10 \%$ maka peneliti melakukan pengujian yang meliputi uji mutu fisik berupa homogenitas, organoleptik, viskositas, $\mathrm{pH}$, daya sebar, dan uji potensi antioksidan dengan menggunakan metode DPPH.

\section{Preparasi Sampel}

Sampel yang digunakan adalah bunga kubis merah (Brassica oleracea L.) segar yang berwarna hijau dibersihkan atau disortasi, kemudian dicuci dengan air mengalir hingga bersih. Sampel bunga kubis merah (Brassica oleracea L.) dikeringkan dengan dianginanginkan selama 3-5 hari. Sampel dihaluskan dengan blender serta diayak dengan pengayak ukuran 40 mesh.

\section{Penentuan Kadar Air}

Penetapan kadar Air dilakukan sesuai dengan prosedur [7]. Cawan porselin dikeringkan pada suhu $105^{\circ} \mathrm{C}$ selama 30 menit lalu dikeringkan dalam deksikator dan ditimbang. Sebanyak 2 gram sampel bunga kubis merah dimasukkan dalam cawan dan dipanaskan pada suhu $105^{\circ} \mathrm{C}$ sampai diperoleh bobot konstan, kemudian didinginkan dalam deksikator dan ditimbang.

\section{Kadar air $=\frac{\text { Simplisia Awal }- \text { Simplisia setelah dikeringkan }}{\text { Simplisia Awal }} \times 100 \%$}

\section{Pembuatan Ekstrak EtanolBunga kubis merah}

Serbuk simplisia bunga kubis merah sebanyak $500 \mathrm{~g}$ dimaserasi dengan menggunakan pelarut etanol $96 \%$ sebanyak $5 \mathrm{~L}$. Serbuk simplisia direndam selama 3 hari, setiap 24 jam maserat disaring, kemudian ditambahkan lagi pelarut etanol $70 \%$. Hasil maserasi kemudian dipekatkan menggunakan rotary evaporator pada suhu $50^{\circ} \mathrm{C}$ sampai diperoleh ekstrak kental bunga kubis merah.

Rendemen ekstrak total dihitung dengan cara membagi berat ekstrak yang dihasilkan dengan berat simplisia serbuk [7]. Perhitungan rendemen ekstrak total dapat dilakukan berdasarkan persamaan berikut:

$\%$ Rendemen ekstrak total $=\frac{\text { Bobot ekstrak yang diperoleh }}{\text { Bobot simplisia serbuk }} \times 100 \%$

\section{Uji Fitokimia [8]}

\section{a. Uji Alkaloid}

Sebanyak $500 \mathrm{mg}$ sampel (ekstrak etanol $96 \%$, ekstrak etil asetat, dan ekstrak nheksan) ditambahkan $1 \mathrm{ml}$ asam klorida $2 \mathrm{~N}$ dan $10 \mathrm{ml}$ air, panaskan di penangas air selama 2 menit, dinginkan dan saring. Kemudian dibagi menjadi 3 tabung reaksi. Pada tabung pertama dimasukkan pereaksi Mayer, hasil dinyatakan (+) jika terbentuk endapan putih. Pada tabung kedua dimasukkan perekasi Dragendorff, hasil 
dinyatakan (+) bila terbentuk endapan merah jingga. Pada tabung ketiga dimasukkan pereaksi Wagner, hasil dinyatakan (+) bila terbentuk endapan coklat.

b. Uji Flavonoid

Sebanyak $500 \mathrm{mg}$ sampel (ekstrak etanol $96 \%$, ekstrak etil asetat, dan ekstrak nheksan) dilarutkan dalam $5 \mathrm{ml}$ air kemudian dipanaskan selama 5 menit setelah itu disaring. Filtrat ditambahkan serbuk magnesium serta $\mathrm{HCl}$ :etanol (1:1) dan amil alkohol. Hasil dinyatakan positif bila terbentuk endapan warna jingga hingga merah ungu.

\section{c. Uji Saponin}

Sebanyak $500 \mathrm{mg}$ sampel (ekstrak etanol $96 \%$, ekstrak etil asetat, dan ekstrak nheksan) ditambahkan $5 \mathrm{ml}$ akuades dalam tabung reaksi. Dikocok kuat-kuat, adanya saponin ditandai dengan terbentuk busa yang stabil.

\section{d. Uji Tanin}

Sebanyak $500 \mathrm{mg}$ sampel (ekstrak etanol $96 \%$, ekstrak etil asetat, dan ekstrak nheksan) direbus dengan $10 \mathrm{ml}$ akuades dalam tabung reaksi selama 5 menit, kemudian disaring. Filtrat ditetesi $\mathrm{FeCl}_{3} 1 \%$. Uji positif ditandai dengan munculnya warna hijau kecoklatan atau biru kehitaman.

e. Uji Steroid

Sebanyak $500 \mathrm{mg}$ sampel (ekstrak etanol $96 \%$, ekstrak etil asetat, dan ekstrak nheksan) ditambahkan etanol kemudian dipanaskan selama 2 menit. Ekstrak disaring dalam keadaan panas kemudian filtrat diuapkan di waterbath sampai kering. Setelah kering ditambahkan $1 \mathrm{ml}$ dietil eter kemudian dihomogenkan selanjutnya ditambahkan 1 tetes $\mathrm{H}_{2} \mathrm{SO}_{4}$ pekat dan 1 tetes $\mathrm{CH}_{3} \mathrm{COOH}$ anhidrat. Uji positif ditandai dengan munculnya warna hijau atau biru.

\section{Formulasi Sediaan Gel}

Bahan uji pada penelitian ini adalah menggunakan ekstrak bunga kubis merah (Brassica oleracea L.) yang diformulasikan kedalam sediaan topikal berupa gel dengan konsentrasi ekstrak bunga kubis merah5, 7.5, dan $10 \%$.

Tabel 1. Formulasi gel ekstrak bunga kubis merah [9]

\begin{tabular}{|c|c|c|c|}
\hline \multirow{2}{*}{ Bahan } & \multicolumn{3}{|c|}{ Konsentrasi (\% b/b) } \\
\cline { 2 - 4 } & $\begin{array}{c}\text { Formul } \\
\text { I }\end{array}$ & Formula & Formula \\
& II & III \\
\hline
\end{tabular}

\begin{tabular}{|c|c|c|c|}
\hline $\begin{array}{l}\text { Ekstrak } \\
\text { etanol } \\
\text { bunga } \\
\text { kubis } \\
\text { merah }\end{array}$ & 5 & 7,5 & 10 \\
\hline HPMC & 7 & 7 & 7 \\
\hline $\begin{array}{l}\text { Propile } \\
\text { nglikol }\end{array}$ & 15 & 15 & 15 \\
\hline $\begin{array}{l}\text { Metil } \\
\text { paraben } \\
\text { Propil } \\
\text { Parabe } \\
\text { n }\end{array}$ & 0,08 & 0,08 & 0,03 \\
\hline $\begin{array}{l}\text { Aquade } \\
\text { st add }\end{array}$ & 100 & 100 & 100 \\
\hline
\end{tabular}

\section{Pembuatan Sediaan Gel}

HPMC didispersikan terlebih dahulu dengan akuades yang telah dipanaskan pada suhu $80-90^{\circ} \mathrm{C}$ dan didiamkan selama 24 jam supaya HPMC mengembang dengan baik. Pembuatan gel dilanjutkan dengan melarutkan metil paraben dan propil paraben ke dalam propilenglikol kemudian ditambahkan ekstrak etanol bunga kubis merah (campuran 1). Campuran 1 ditambahkan ke dalam HPMC yang telah mengembang disertai dengan pengadukan hingga homogen.

\section{Evaluasi Sediaan Gel}

\section{a. Uji Penampilan Fisik (Organoleptik)}

Uji penampilan fisik (organoleptik) sediaan gel dengan melihat homogenitas gel, bau dan warna sediaan yang telah dibuat [10].

\section{b. Uji Homogenitas}

Uji homogenitas dilakukan untuk melihat apakah sediaan yang telah dibuat homogen atau tidak. Caranya, gel dioleskan pada kaca transparan dimana sediaan diambil 3 bagian yaitu atas, tengah dan bawah. Homogenitas ditunjukan dengan tidak adanya butiran kasar [10]

\section{c. Uji pH}

Uji pH dilakukan untuk melihat tingkat keasaman sediaan gel untuk menjamin sediaan gel tidak menyebabkan iritasi pada kulit. $\mathrm{pH}$ sediaan gel diukur dengan menggunakan $\mathrm{pH}$ stick universal. $\mathrm{pH}$ sediaan yang memenuhi kriteria pH kulit yaitu dalam range 4,5-6,5 [11].

\section{d. Viskositas}

Pengukuran viskositas dilakukan dengan menggunakan alat viskometer Brookfield. Cara 
pengujian, yaitu sediaan gel dimasukkan ke dalam wadah berupa gelas piala $100 \mathrm{ml}$, spindel yang sesuai diturunkan hingga batas spindel tercelup ke dalam gel, kemudian motor dan spindel nomer 3 dinyalakan. Angka viskositas yang ditunjukkan oleh jarum merah dicatat, kemudian dikalikan dengan suatu faktor yang dapat dilihat pada tabel yang terdapat pada brosur alat [12].

\section{e. Daya Sebar}

Uji daya sebar dilakukan untuk menjamin pemerataan gel saat diaplikasikan pada kulit dilakukan segera setelah gel dibuat. Gel ditimbang sebanyak $0,5 \mathrm{~g}$ kemudiaan diletakkan ditengah kaca bulat lain atau bahan transparan lain dan pemberat sehingga berat kaca bulat dan pemberat $150 \mathrm{~g}$, didiamkan 1 menit, kemudian dicatat diameter penyebarannya. Daya sebar gel yang baik antara 5-7 cm [10].

\section{Uji Stabilitas}

a. Uji stabilitas pada suhu panas

Pengujian stabilitas sediaan meliputi bau, warna dan $\mathrm{pH}$ dievaluasi pada suhu tinggi yaitu $\left(40^{\circ} \mathrm{C} \pm 2^{\circ} \mathrm{C}\right)$ selama 4 minggu kemudian pengamatan dilakukan setiap 1 minggu sekali [14].

b. Uji stabilitas pada suhu kamar

Pengujian stabilitas sediaan meliputi bau, warna dan $\mathrm{pH}$ dievaluasi pada suhu kamar $\left(27^{\circ} \mathrm{C} \pm 2^{\circ} \mathrm{C}\right)$ selama 4 minggu dengan pengamatan setiap 1 minggu sekali [13].

\section{Uji Antioksidan Dengan DPPH}

Metode yang dipakai untuk menganalisis daya antioksidan ada beberapa metode, salah satu metode yang sering digunakan adalah metode DPPH (2,2-difenil-1-picrylhidrazyl) uji DPPH berdasarkan pada pengukuran penentuan absorbsi DPPH pada panjang maksimum 514$517 \mathrm{~nm}$. Penurunan ini sebanding dengan konsentrasi menghambat radikal bebas yang ditambahkan pada larutan DPPH.

\section{a. Pembuatan Larutan DPPH $(0,2 \mathrm{mM})$}

Sebanyak 7,9 mg DPPH (BM 394,32 g/mol) ditimbang, dilarutkandengan etanol $96 \%$ sebanyak 100 mLke dalam labu ukur $100 \mathrm{~mL}$, sehingga diperoleh larutan DPPH dengan konsentrasi 0,2 mM. Larutan disimpan pada suhu rendah, terlindung dari cahaya untuk segera digunakan.

\section{b. Pembuatan Larutan Blanko}

Dilakukan dengan memipet $\mathrm{mL}$ larutan DPPH 0,2 $\mathrm{mM}$ kedalam tabung reaksi yang telah ditara $5 \mathrm{~mL}$, lalu ditambahkan etanol 96\% hingga tanda batas volume. Kemudian, larutan blanko diinkubasi pada temperatur $37^{\circ} \mathrm{C}$ selama 30 menit.

\section{c. Pembuatan Larutan Kontrol (Vitamin C)}

Larutan induk dibuat dengan cara menimbang seksama $100 \mathrm{mg}$ vitamin $\mathrm{C}$, dilarutkan dalam $100 \mathrm{~mL}$ etanol $96 \%$ dengan konsentrasi menjadi 1000 ppm, dipipet dimasukkan masing-masing pada labu ukur 100 mL sebanyak $0,5 \mathrm{~mL} ; 0,75 \mathrm{~mL} ; 1 \mathrm{~mL} ; 1,25 \mathrm{~mL}$ $1,5 \mathrm{~mL}$ dari larutan induk. Kemudian di tera dengan etanol $96 \%$ hingga $100 \mathrm{~mL}$. dibuat seri konsentrasi pada masing-masing ialah 5 ppm; 7,5 ppm; 10 ppm; 12,5 ppm; 15 ppm. Larutan diinkubasi pada temperatur $37^{\circ} \mathrm{C}$ selama 30 menit. Absorbansinya diukur dengan spektrofotometer UV-Vis.

\section{d. PembuatanLarutan Sampel Sediaan Gel dan Ekstrak Bunga Kubis Merah}

Larutan uji dibuat dengan cara menimbang seksama $100 \mathrm{mg}$ gel atau ekstrak bunga kubis merah, dilarutkan dalam $100 \mathrm{~mL}$ etanol $96 \%$ dengan konsentrasi menjadi 1000 ppm,dipipet dan dimasukkan pada masing-masing labu ukur $100 \mathrm{~mL}$ sebanyak $1 \mathrm{~mL} ; 2,5 \mathrm{~mL} ; 5 \mathrm{~mL}$; 7,5 mL; $10 \mathrm{~mL}$. Kemudian ditera dengan etanol $96 \%$ hingga mencapai $100 \mathrm{~mL}$. dibuat seri untuk mendapatkan konsentrasi sampel $10 \mathrm{ppm} ; 25$ ppm; 50 ppm; 75 ppm; 100 ppm. Selanjutnya, larutan diinkubasi pada temperatur $37^{\circ} \mathrm{C}$ selama 30 menit. Absorbansinya diukur dengan spektrofotometer UV-Vis. Aktivitas antioksidan sampel ditentukan oleh besarnya hambatan serapan radikal DPPH melalui perhitungan persentase inhibisi serapan DPPH dengan rumus:

$\%$ Inhibisi $=\frac{\text { Ablanko-Asampel }}{\text { Ablanko }} \times 100 \%$

Keterangan :

$\mathrm{A}=$ Nilai Absorbansi 
Selanjutnya diperoleh persentase inhibisi dari masing-masing konsentrasi dilanjutkan dengan perhitungan secara regresi linear menggunakan persamaan $\mathrm{y}=\mathrm{ax}+\mathrm{b}$, dimana $\mathrm{y}=50$ dan $\mathrm{x}$ menunjukkan $\mathrm{IC}_{50}$. Aktivitas antioksidan dinyatakan dengan Inhibitio concentration $50 \%$ atau $\mathrm{IC}_{50}$ yaitu konsentrasi sampel yang dapat meredam radikal DPPH sebanyak 50\%.

\section{HASIL DAN PEMBAHASAN Simplisia}

Sampel yang digunakan pada penelitian ini adalah bunga kubis merah (Brassica oleracea L.) Simplisia bunga kubis merah dibuat serbuk dan diayak dengan p engayak 40 mesh. Setelah pengayakan, serbuk bunga kubis merah diukur kadar airnya. Penentuan kadar air berguna untuk mengetahui batasan maksimal atau kisaran kandungan air dalam bahan. Hal ini berhubungan dengan daya simpan simplisia, sehingga jika melebihi batas yang ditentukan sangat mempengaruhi waktu kadaluarsa dari simplisia tersebut.

Semakin tinggi kadar air, maka semakin mudah ditumbuhi jamur dan kapang sehingga dapat menurunkan aktivitas biologi senyawa aktif selama penyimpanan. Jumlah kadar air yang baik pada daun, yaitu $\leq 10 \%$ [7]. Hasil penetapan kadar air yang diperoleh pada penelitian ini adalah 7,83\% yang artinya kadar air ekstrak bunga kubis merah telah memenuhi persyaratan sehingga tidak mudah ditumbuhi jamur dan kapang, serta dapat disimpan dalam waktu yang cukup lama.

\section{Hasil Ekstraksi Bunga Kubis Merah}

Metode ekstraksi yang digunakan pada penelitian ini yaitu metode maserasi menggunakan pelarut etanol 96\%. Ekstraksi dengan pelarut etanol $96 \%$ pada bunga kubis merah didapatkan hasil ekstrak berwarna cokelat tua dan berbau khas kubis. Hasil ekstraksi selanjutnya dilakukan perhitungan persen rendemen yaitu berat ekstrak kental 125 $\mathrm{g}$ dan hasil rendemen 20,83\%. Dapat disimpulkan rendemen ekstrak memiliki rendemen yang kecil.

\section{Hasil Fitokimia Ekstrak Etanol Bunga Kubis Merah}

Komponen-komponen senyawa bioaktif pada sampel uji dapat diketahui melalui uji fitokimia. Uji fitokimia yang dilakukan pada penelitian ini adalah identifikasi alkaloid, flavonoid, saponin, tanin, triterpenoid dan steroid. Hasil dari uji fitokimia ekstrak etanol bunga kubis merah menunjukkan hasil positif pada pengujian senyawa golongan flavonoid, saponin, dan tanin.

Tabel 2. Hasil Uji Fitokimia Ekstrak Etanol 70\% Bunga Kubis Merah (Brassica oleracea L.)

\begin{tabular}{|c|c|c|}
\hline Pengujian & Hasil & Simpulan \\
\hline $\begin{array}{l}\text { Alkaloid } \\
\text { Pereaksi }\end{array}$ & $\begin{array}{l}\text { Terdapat } \\
\text { endapan putih }\end{array}$ & \\
\hline Mayer & Terdapat & - \\
\hline Pereaksi & endapan & \\
\hline Wagner & kuning & \\
\hline Pereaksi & kecoklatan & \\
\hline Dragendroff & $\begin{array}{l}\text { Terdapat } \\
\text { endapan } \\
\text { kuning }\end{array}$ & \\
\hline \multirow[t]{2}{*}{ Flavonoid } & Terdapat & \\
\hline & $\begin{array}{l}\text { lapisan kuning } \\
\text { pada lapisan } \\
\text { amil alkohol }\end{array}$ & + \\
\hline Saponin & $\begin{array}{l}\text { Tidak terdapat } \\
\text { buih }\end{array}$ & + \\
\hline Tanin & $\begin{array}{l}\text { Terjadi warna } \\
\text { hijau }\end{array}$ & + \\
\hline & kehitaman & \\
\hline Terpenoid & $\begin{array}{l}\text { Terdapat } \\
\text { warna merah }\end{array}$ & - \\
\hline & $\begin{array}{l}\text { (+) hasil menun } \\
(-) \text { hasil menun }\end{array}$ & $\begin{array}{l}\text { an positif } \\
\text { an negatiif }\end{array}$ \\
\hline
\end{tabular}

\section{Uji Organoleptik Sediaan Gel Ekstrak Etanol Bunga Kubis Merah (Brassica oleracea $\mathbf{L}$.)}

Pengujian organoleptik sediaan gel ekstrak bunga kubis merah dilakukan dengan mengamati sediaan gel berdasarkan bentuk, warna dan bau. Gel ekstrak bunga kubis merah memberikan bau yang khas dari bunga kubis merah dan memiliki tekstur lembut. Bentuk sediaan gel dalam bentuk semi solid dan warna gel dengan konsentrasi 5\% memiliki warna cokelat muda, karena sediaan gel tersebut mengandung ekstrak yang tidak terlalu banyak, sehingga masih bercampur dengan basis gel. Gel dengan konsentrasi 7.5\% berwarna cokelat, sedangkan gel dengan konsentrasi $10 \%$ memiliki warna cokelat tua karena kandungan ekstraknya banyak. 
34 | Ferry Effendi et al., (Formulasi Sediaan Gel Ekstrak Etanol Bunga Kubis Merah...)

Tabel 3. Hasil Uji Organoleptik Gell Ekstrak Bunga Kubis Merah

\begin{tabular}{cccc}
\hline Gel & Warna & Aroma & Tekstur \\
\hline $\begin{array}{c}\text { Formula } \\
\mathbf{1}\end{array}$ & Coklat & ++ & Lembut \\
$\begin{array}{c}\text { Formula } \\
\mathbf{2}\end{array}$ & Coklat & ++ & Lembut \\
$\begin{array}{c}\text { Formula } \\
\mathbf{3}\end{array}$ & $\begin{array}{c}\text { Coklat } \\
\text { Tua }\end{array}$ & +++ & Lembut \\
\hline Uji Homogenitas & & \\
\hline
\end{tabular}

Tabel 4. Hasil Uji Homogenitas Gel Ekstrak Bunga Kubis Merah

\begin{tabular}{|c|c|}
\hline Jenis Gel & Homogenitas \\
\hline Formula I & $\begin{array}{c}\text { Homogen dan } \\
\text { tidak ada partikel }\end{array}$ \\
\hline Formula II & $\begin{array}{l}\text { Homogen dan } \\
\text { tidak ada partikel }\end{array}$ \\
\hline Formula III & $\begin{array}{c}\text { Homogen dan } \\
\text { tidak ada partikel }\end{array}$ \\
\hline
\end{tabular}

Uji Homogenitas sediaan gel yang dilakukan memberikan hasil yang homogen serta tidak adanya gumpalan atau butiran kasar pada sediaan gel ekstrak etanol bunga kubis merah (Brassica oleracea L.). Sediaan gel yang homogen mengindikasikan bahwa bahan-bahan atau komposisi yang digunakan tercampur secara baik dan merata.

\section{Uji PH}

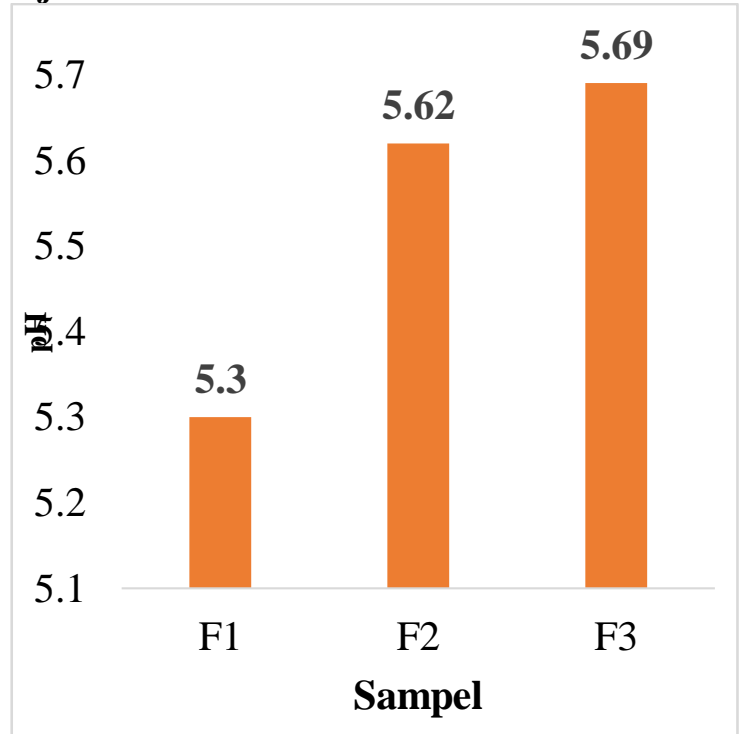

Gambar 1. Hasil Uji pH Sediaan Gel Ekstrak Etanol bunga kubis merah (Brassica oleracea $\mathbf{L}$.).
Hasil pengujian $\mathrm{pH}$ yang dilakukan pada sediaan gel memenuhi persyaratan yang sesuai dengan $\mathrm{pH}$ kulit yaitu 4,5-6,5 sehingga aman untuk digunakan, karena $\mathrm{pH}$ yang terlalu asam dapat menyebabkan iritasi kulit sedangkan $\mathrm{pH}$ yang terlalu basa dapat menyebabkan kulit kering dan bersisik.

\section{Uji Viskositas}

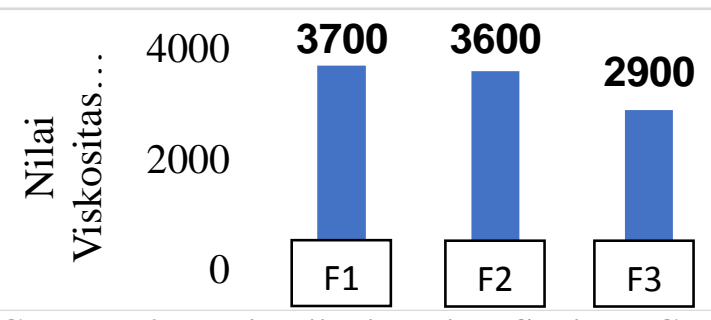

Gambar 2. Hasil Uji Viskositas Sediaan Gel Ekstrak Etanol Bunga Kubis Merah (Brassica oleracea L.).

Viskositas adalah sifat yang menentukan daya tahannya terhadap gaya geser. Hasil uji viskositas pada sediaan gel ekstrak etanol $70 \%$ bunga kubis merah (Brassica oleracea L.) yang memiliki viskositas tertinggi yaitu pada Formula I dengan nilai viskositas yaitu 3.700 cps, kemudian formula II yaitu $3.600 \mathrm{cps}$, dan formula III yaitu $2.900 \mathrm{cps}$. Menurut Grag A. et al nilai viskositas sediaan yang baik yaitu 2000 - $4000 \mathrm{cps}$, artinya sediaan kontrol dan formula I memenuhi kriteria sebagai sediaan yang baik [14].

\section{Uji Daya Sebar}

Uji daya sebar yang dilakukan dengan cara meletakan gel diatas plat kaca, kaca lainnya diletakkan diatasnya dan diberi beban sampai 100 gr selama 1 menit kemudian dihitung diameternya. Hasil uji daya sebar bertujuan untuk mengetahui kemampuan gel menyebar pada kulit. Sediaan yang nyaman digunakan memiliki daya sebar antara 5 sampai $7 \mathrm{~cm}$ [14]. 


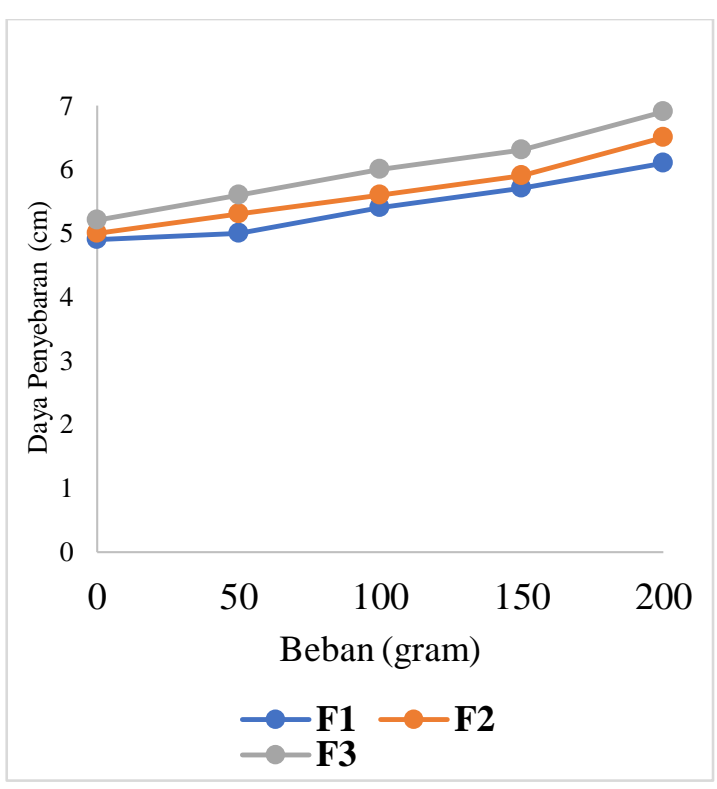

Gambar 3. Hasil Uji Daya Sebar

Hasil pengujian daya sebar gel menggunakan basis HPMC dan dengan menggunakan ekstrak etanol bunga kubis merah memenuhi kriteria daya sebar untuk sediaan gel. Penambahan ekstrak mempengaruhi viskositas sehingga daya sebar terhadap sediaan menaik.

Hasil Uji Antioksidan Ekstrak Kental, Vitamin C dan Gel Ekstrak Etanol Bunga Kubis Merah

Tabel 5. Hasil Uji Fitokimia Ekstrak Kental, Vitamin C dan Gel Ekstrak Etanol Bunga Kubis Merah (Brassica oleracea L.)

\begin{tabular}{lll}
\hline \multicolumn{1}{c}{ Sampel } & \multicolumn{1}{c}{$\begin{array}{c}\text { Nilai IC } \\
(\mathbf{p p m})\end{array}$} & $\begin{array}{c}\text { Kategori } \\
(\text { Molyneux, } \\
\mathbf{2 0 0 4})\end{array}$ \\
\hline F1 & 80,15 & Kuat \\
F2 & 59,71 & Kuat \\
F3 & 57,48 & Kuat \\
Ekstrak & 47,10 & Sangat Kuat \\
Vitamin C & 6,30 & Sangat Kuat \\
\hline
\end{tabular}

Berdasarkan pada hasil uji aktivitas antioksidan ketiga formulasi memiliki aktivitas antioksidan kategori kuat. Hasil pengujian menunjukkan F3 memiliki nilai aktivitas antioksidan lebih baik dibandingkan F2 dan F1, hal ini ditunjukkan dengan nilai $\mathrm{IC}_{50} \mathrm{~F} 3$, yaitu sebesar 57,48 sedangkan F1 sebesar 80,15 dan F2 sebesar 59,71. Pada F3 konsentrasi ekstrak etanol bunga kubis merah yang ditambahkan ke dalam sediaan gel sebesar $10 \%$ lebih banyak dibandingkan F1 dan F2.

Nilai $\mathrm{IC}_{50}$ ekstrak sebesar $47,10 \mathrm{ppm}$, dan aktivitas antioksidannya lebih kuat dibanding yang telah dibuat sediaan. Aktivitas antioksidan setelah dibuat sediaan menjadi lebih tinggi $\mathrm{IC}_{50}$ nya karena kemungkinan terjadi reaksi antara ekstrak dengan salah satu komponen dalam sediaan gel, sehingga aktivitas antioksidan sediaan lebih kecil dari ekstrak. Vitamin $\mathrm{C}$ sebagai pembanding memiliki nilai $\mathrm{IC}_{50}$ sebesar 6,30 yang termasuk kategori sangat kuat.

\section{SIMPULAN}

Hasil penelitian menunjukkan bahwa:

1. Aktivitas antioksidan ekstrak etanol bunga kubis merah dan Vitamin C sebagai senyawa pembanding memiliki kategori $\mathrm{IC}_{50}$ yang sangat kuat yaitu sebesar $47,10 \mathrm{ppm}$ dan $6,30 \mathrm{ppm}$.

2. Konsentrasi ekstrak pada sediaan gel memberikan pengaruh yang berbeda terhadap nilai $\mathrm{pH}$, viskositas, organoleptik, daya sebar, dan aktivitas antioksidan.

3. Sediaan gel pada formulasi 3 dengan konsentrasi ekstrak etanol bunga kubis merah $10 \%$ memiliki aktivitas antioksidan paling kuat dari ketiga konsentrasi dengan nilai $\mathrm{IC}_{50}$ sebesar 57,48 ppm, konsentrasi ekstrak 7,5\% sebesar 59,71 ppm dan konsentrasi ekstrak 5\% sebesar 80,15 ppm.

\section{DAFTAR PUSTAKA}

[1] Balitbang. 1993. Budidaya Tanaman Kubis. Lembar Informasi Pertanian (LIPTAN). Kementrian Pertanian.

[2] Rokayya, S., Chun, J. L., Yan, Z., Ying, L., dan Chang, H. S., 2013. Cabbage (Brassica oleracea L. var. capitata) Phytochemicals with Antioxidant and Anti-inflammatory Potential. JournalAsian Pac J Cancer Prev. Vol : 14 (11): 6657-6662.

[3] Wahyuni, D. I. 2017. Uji Aktivitas Ekstrak Etanol dan Etil Asetat Kubis Ungu (Brassica oleraceae L.) dalam Menurunkan Kadar Gula Darah Mencit Jantan. [Skripsi]. Universitas Sumatera Utara.

[4] Agoes, G., 2009, Teknologi Bahan Alam (Serial Farmasi Industri- 2). Edisi II. 
36 | Ferry Effendi et al., (Formulasi Sediaan Gel Ekstrak Etanol Bunga Kubis Merah...)

Penerbit: Institut Teknologi Bandung: 55-68.

[5] Mitsui, T., 1997. New Cosmetic Science, Elsevier ScienceB.V, Journal The Netherland Amsterdam. Vol : 3 (1): 3338.

[6] Diana, D. Z., and Thaman, A. L., 2006. Cosmetic Formulation of Skin Care Product, Taylor and Francis Group, New York, London: 135-138.

[7] Departemen Kesehatan 1995. Materia Medika Indonesia Jilid I-IV. Jakarta :Menteri Kesehatan Indonesia.

[8] Harborne, 1996. Metode Fitokimia Penuntun Cara Modern Menganalisis Tumbuhan. Terbitan kedua. Terjemahan K. Padmawinata dan 1. Soediro. Bandung: ITB.

[9] Arikumalasari, J., 2013, Optimasi HPMC Sebagai Gelling Agent Dalam Formula Gel Ekstrak Kulit Buah Manggis (Garcinia mangostana L.): 145-152.

[10] Mappa, Tiara, Eddy H.J., Kojong. N. 2013. Formulasi Gel Ekstrak Daun Sasaladahan (Peperomia pellucida (L.) H.B.K) dan Uji Efektivitasnya Terhadap Luka Bakar Pada Kelinci (Oryctolagus Cuniculus). Jurnal Ilmiah Farmasi Vol 2(2): 51 .

[11] Tranggono dan Latifah. 2007. Buku Pegangan Ilmu Pengetahuan Kosmetik. Jakarta: Penerbit Pustaka Utama: 12-22.

[12] Rahmawanty., Dina 2014. Formulasi Gel Menggunakan Serbuk Daging Ikan Haruan (Channa striatus)Sebagai Penyembuh Luka: 11 - 33.

[13] Agoes, G. \& Darijanto, S.T., 2013, Teknologi Farmasi Likuida Dan Semi Solida.Bandung: Pusat Antar Universitas Bidang Ilmu Hayati ITB: 4-6

[14] Grag, A.,Aggarwal, D., Garg, S., Singla, S.A. 2002. Spreading of semisolid formulation. Journal update Pharmacetical Technology, 2002:84-104. 